Les circulations en santé : des produits, des savoirs, des personnes en mouvement | 2019

\title{
Medicine at the border: resort to afghans health professionals in a humanitarian emergency context
}

\section{Chloé Tisserand}

\section{(2) OpenEdition \\ 1 Journals}

Electronic version

URL: http://journals.openedition.org/rfst/820

DOI: $10.4000 /$ rfst.820

ISSN: 2492-3672

Publisher

Espaces et SOciétés (UMR 6590)

\section{Electronic reference}

Chloé Tisserand, "Medicine at the border: resort to afghans health professionals in a humanitarian emergency context", Revue francophone sur la santé et les territoires [Online], Healthy circulation: products, knowledge, people on the move, Online since 16 December 2019, connection on 06 April 2021. URL: http://journals.openedition.org/rfst/820 ; DOI: https://doi.org/10.4000/rfst.820

This text was automatically generated on 6 April 2021.

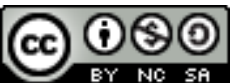

La Revue francophone sur la santé et les territoires est mise à disposition selon les termes de la Licence Creative Commons Attribution - Pas d'Utilisation Commerciale - Partage dans les Mêmes Conditions 4.0 International. 


\title{
Medicine at the border: resort to afghans health professionals in a humanitarian emergency context
}

\author{
Chloé Tisserand
}

1 Calais is a "border area" (Cuttitta, 2015). In 2014, the increase in the number of exiles forced the hospital to develop its medical team attached to the permanent health care access service (PASS), which provides free hospital medicine for vulnerable patients without social security coverage. The rapport of professionals towards precariousness has been the subject of several sociological studies that have shown that caregivers in hospitals can express disgust towards patients at the margins. In its ancestral form, the hospital welcomes "these people too" (Castel, 1995) but the creation of university hospital centers (CHU) in 1958 has spread somewhat this social dimension in favor of technical prowess and specialties. We will first see how caregivers reclassified exiles as a resource for the hospital to extend medicine to the precarious. This category of professionals comes together and resembles each other because they share the test of medical disconnection that they have known on their professional trajectory. In the absence of sufficient applications, the institution used Afghan doctors who worked with French carers (nurses, doctors, psychologists, etc.). The metamorphoses of the PASS related to the adaptation of the migratory movements thus favor the circulation of the professionals: hospital doctors (French and Afghans), paramedics providing specialized services (pneumology, EHPAD, traumatology, etc.), some of whom are seeking occupational reclassification. There is also a turnover of caregivers that makes the hospital a potential place for the circulation of knowledge and exchanges. This experience produced intercultural exchanges between professionals in the care of precarious exiles. Exiled carers become cultural Interpreters. Because they often speak the language of their patients and they know their culture, the mobilization of these skills informs health professionals and reduces the gap that exists between French health professionals and treated exiles. Their cultural affiliation is an asset but can also be turned against them in the relationship with precarious exiled patients. Being Afghan presents advantages and may also pose difficulties in the form of reluctance, 
albeit rarely, on the part of patients. There is a risk of mirror effect because carers and caregivers share a common experience, which can lead caregivers to redouble their efforts at work. However, it is compassion that predominates these relationships and the common experience of exile - even if the exiled caregivers seem more fortunate than their patients - brings them closer and exposes them more than French health care providers. Through this feeling of being useful, they permeate, like the reclassified paramedics, the meaning of their work. But more than a place of intercultural sharing, PASS is a springboard for these exiled carers in a situation of social disaffiliation (Castel, 1995), since they have taken the same roads of exile as their patients and who wish to rebuild their professional identity. Exile is a shock, a crack since "tearing out the country" (Laacher, 2005) implies a situation of radical rupture. Caregivers had to give up their social status to blend in with those who find themselves on the roads; they become like other exiles, "supernumeraries" (Castel, 1995). Thus, the first job they acquire in a French hospital may allow them to evolve from status to status and finally obtain their equivalence in terms of the specialty they were practicing in Afghanistan.

Photo: The Afghan doctor, standing, looks attentively at the French nurse who bandage the patient's foot to cure an abscess.

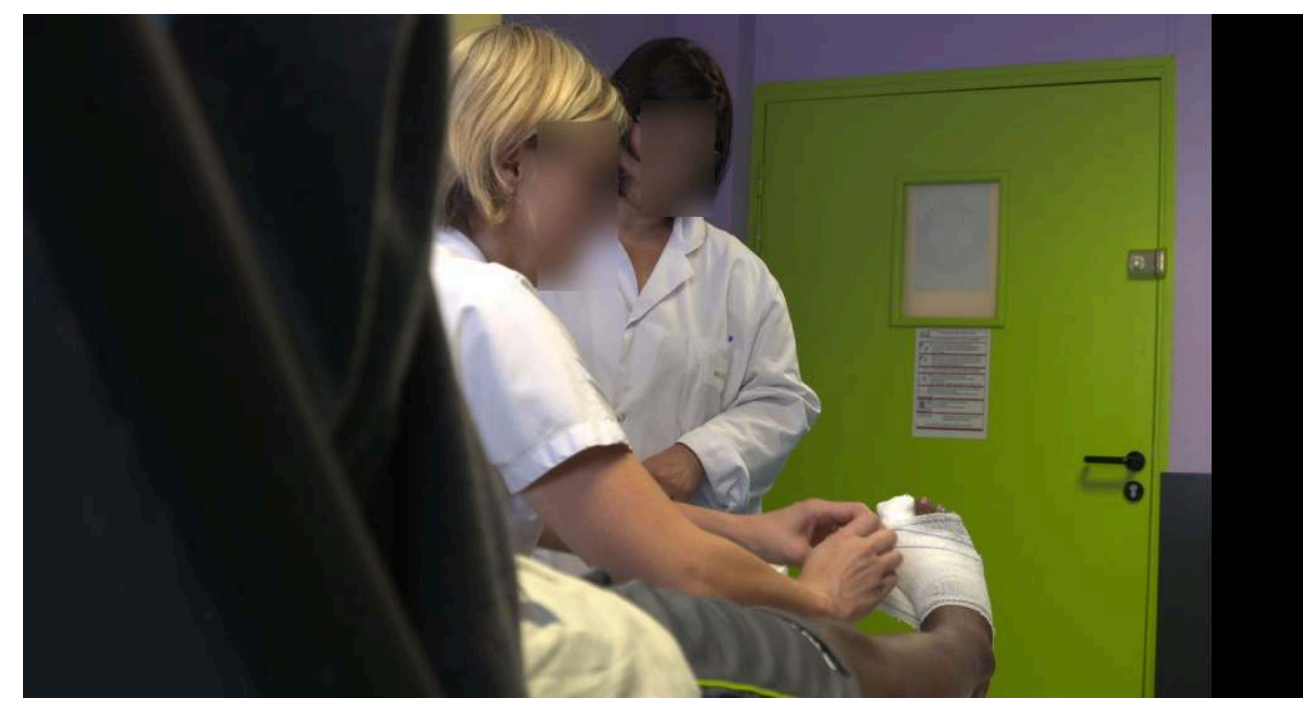

\section{BIBLIOGRAPHY}

Castel Robert, 1995, Les métamorphoses de la question sociale, Paris : Gallimard.

Cuttitta P., 2015, La frontière Lampedusa. Mises en intrigue du sécuritaire et de l'humanitaire. Cultures \& Conflits. 99-100, (3), pp. 99-115. doi:10.4000/conflits.19101

Laacher, Smain, 2005, Éléments pour une sociologie de l'exil. Politix. № 69, pp. 101-128. doi: 10.3917/pox.069.0101

Revue francophone sur la santé et les territoires, Les circulations en santé : des produits, des savoirs, des personnes en mouvement 
INDEX

Geographical index: Afghanistan

Keywords: border, circulation, humanitarian medicine

\section{AUTHOR}

\section{CHLOÉ TISSERAND}

Doctorante au centre de recherche "Individus, épreuves et sociétés" (CeRIES) à l'Université de Lille. Fellow à l'Institut convergences migrations (ICM) à Paris 